\title{
Urban and rural perceptions of mental illness in Ethiopia
}

\author{
${ }^{1}$ Nicole M. Monteiro, Ph.D. and ${ }^{2}$ Shyngle K. Balogun, Ph.D. \\ ${ }^{I}$ Department of Psychology, University of Botswana, Botswana, Address: Private Bag 00775, Gaborone \\ ${ }^{2}$ Department of Psychology, University of Botswana, Botswana, Address: Private Bag 00775, Gaborone
}

\begin{abstract}
This study explores the impact of social environment on perceptions of mental illness in Ethiopia. Specifically, urban and rural Ethiopians' attitudes, beliefs and practices associated with the symptoms, causes and treatment of mental illness were compared. One hundred and fifteen participants were interviewed using a semi-structured questionnaire to explore their perceptions of depression, anxiety and psychosis. Qualitative analysis of the interview responses indicated a number of similarities, as well as important differences in urban and rural beliefs about the recognition and etiology of mental illness. Responses were categorized as focusing on spiritual, psycho-cultural or socio-economic explanations of mental illness. Rural residents emphasized spiritual and socio-economic indicators of mental illness, while urban residents highlighted culturally inappropriate and disruptive behaviors as signs of mental illness. Both groups overwhelmingly indicated modern psychiatric treatment was the best option to treat mental illness. However, rural residents were more likely to endorse traditional treatment and urban residents were more likely to cite a combination of modern and traditional treatment. Implications for clinical assessment and policy planning are discussed.

Keywords: Africa, Ethiopia, Mental Illness, Perceptions, Rural, Urban
\end{abstract}

\section{Introduction}

Developing a clearer understanding of the relationship between culture and perceptions of mental illness should include examinations of the specific environmental and social variables that impact attitudes, beliefs and practices. One of the most salient social dichotomies impacting how mental illness is experienced and perceived is the rural/urban distinction. It is well understood that psychiatric diagnoses are influenced by the immediate social and physical environment in which individuals develop and live. Although most people throughout Africa live in rural areas (World Bank, 2013), rapid urbanization is contributing to population-wide shifts in values as well as economic, social, and psychological changes within communities.

In Ethiopia, urbanization has steadily increased since 1950 (U.N., 2003). However, less than 20\% of the population live in urban areas (C.I.A., 2013). The majority are still considered rural dwellers. In addition, while the country's mental health policy includes access to care throughout the country (WHO, 2005), resources and access to formal care tend to be centralized in the urban capital, Addis Ababa.

Given this context of social change in Ethiopia, it is important to develop a clearer picture of how rural and urban perceptions of mental illness converge and diverge. Global mental health research has shown that traditionally, rural residents tend to lean toward spiritual understandings of mental illness, while urban residents may gravitate to medical explanations and treatments (Bouhlel et al., 2012; Kishore, Gupta, Jiloha, \& Bantman, 2011). But, do those differences in health beliefs hold up in Ethiopia? If so, are there other areas where perceptions of mental illness overlap?

This study examines perceptions of mental illness in a rural and urban area of Ethiopia. The aim is to develop a richer understanding of how attitudes, beliefs and practices regarding mental illness are affected by differences in the social environment that rural and urban dwellers inhabit.

\section{Urbanization and mental illness}

Marsella (1998) defines urbanization as the "dynamic process and product that emerges from the complex interaction of population, geographical, historical, cultural, economic and political forces...with resulting patterns of psychosocial adjustment and adaptation" (p. 626). It is estimated that half of world's population live in urban areas, with most of the growth occurring in developing countries (Cohen, 2006).

Many researchers have become interested in the mental health consequences of urbanization, particularly in developing countries. They have researched the differences between urban and rural environments, pointing out the benefits and drawbacks of both. Psychological research has focused its impact on various psychiatric disorders, psychological distress, and social deviancy.

Reported global findings related to urbanization and mental health includes: 1.) In Tokyo, some of the psychological symptoms associated with urbanization there are aggression, isolation, apathy and anxiety (Homma, 1991); 2.) In Taiwan, the finding that women in rural areas were more depressed than women in urban 
areas and migrant women was attributed to the rural setting's chronic stressors (Cheng, Soong, Chong, \& Lin, 1995); 3.) Marsella (1998) reported findings from Peru in which urban subjects had higher rates of depression and alcoholism than did rural residents and migrants from rural to urban environments had higher levels of depressive reactions and psychosomatic disorders; 4.) Citing findings that in Brazil rural women migrants who were displaced from the urban labor force had higher morbidity for psychiatric disorders, Almeida-Filho, Mari, \& Coutinho (1995) suggested the real problematic issues of urbanization are economic and political control and oppression; 5.) Findings that in India, Chile and Brazil low-income, slum dwelling, uneducated women reported a high number of symptoms led to the conclusion that severe stressors place urban women in developing countries at psychological risk (Blue, Ducci, Jaswal, Ludermir, \& Harpham, 1995); 6.) In the U.S., young urban women were reported to be at risk for depression, while single rural women were reported to be at risk for depression and alcohol and substance abuse (Marsella, 1998).

It has been suggested that some of the findings support the idea that traditional lifestyles can serve as a buffer against mental illness by encouraging patterns of social relationships, attachments and support that reduce the stressful impact of certain life changes (Marsella, 1998). It is important to consider indigenous concepts of health and disease in the examination of urbanization and mental health. The implications for urbanization may differ for non-Western countries and the buffer of rural life may operate differently in various countries (Marsella, 1998). What may be problematic about urbanization is the erosion of traditional values without a cohesive set of ideals to replace them.

\section{The context of traditional healing in Africa}

Recent patterns of urbanization in African nations have been correlated with changes in the prevalence and symptomatology of psychiatric disorders (Marsella, 1998). In addition, there is acknowledgement of the inadequacy of modern psychiatric care and services throughout Africa to meet these challenges. However, despite the lack of a strong psychiatry infrastructure, there is agreement that there exists a "long history of traditional treatments and management of the broad array of mental disorders that are recognized in the West" (Madu \& Ohaeri, 1989, p.384). In most African societies, mental illness is traditionally included within the scope of problems addressed by traditional healers.

Traditional healers in Africa are commonly classified as herbalists, who specialize in the use of plants, roots and herbs, or diviners, who use incantations and divinations and act as spirit mediums (Odejide, Oyewunmi, \& Ohaeri, 1989). Both types of healers usually have a considerable amount of insight into the patient's experience. Some specific practices include ritual sacrifices, the use of herbal medicines, and extended residential stays at the healer's compound. Other, more dangerous, methods are flogging and physical restraint (Sijuwola, 1995). Religious beliefs influence treatment techniques. Christian methods include fasting, prayer and use of holy water. Christian faith healers in many regions of Africa combine elements of Pentecostal beliefs and indigenous practices. Islamic methods include prayer, drinking the ink used to write Qur'an verses, and the use of amulets containing Qur'an verses to ward off evil spirits (Sijuwola, 1995). Swartz (1995) raises the issue of how lack of resources, in addition to widespread belief in traditional medicine, influences people's reliance on traditional practitioners. In other words, how much "choice" do people really have in terms of healthcare options? Swartz (1995) thinks very little.

\section{Rationale for current study}

Given the complex factors that impact mental illness, it is necessary to clarify patterns of urban and rural perceptions. This will contribute to the general understanding of how culture, urbanization, development and mental illness interact and elucidate the dynamics of urban and rural beliefs about mental illness.

This study explored the following questions using qualitative interviews:

1. What are urban and rural Ethiopians' ideas about the definition and expression, causation and treatment of mental illness?

3. How do urban and rural residents differ in their attitudes, beliefs and practices regarding mental illness?

2. What are perceptions of depression, anxiety and psychosis among urban and rural residents?

4. How do urban and rural residents differ in their use of spiritual, psycho-cultural and socio-economic explanations of mental illness? 


\section{Methods}

\section{General design}

The research design was cross-sectional survey utilizing a qualitative semi-structured questionnaire to interview participants.

\section{Population and setting}

Interviews were conducted with participants in Addis Ababa and Asella. Addis Ababa is the capital and the economic, political, and educational center of Ethiopia. It is a densely populated city inhabited by people of multiple ethnic groups from all over the country, as well as refugees and ex-patriots from other countries. The rural area was the town of Arsi in the district of Asella, which is $420 \mathrm{~km}$ south of Addis Ababa. It is a small town surrounded by peasant dwellings.

\section{Participants}

One hundred and fifteen participants completed the interview questionnaire. They were selected using purposive sampling. Inclusion criteria for participants were: males and females age 16 and older, Ethiopian nationals and residents of the respective study regions, Addis Ababa and Asella. Participants were selected from the following specific locations in Addis Ababa and Asella: secondary schools; Addis Ababa University; hospitals; churches; neighborhoods and community dwellings.

Sixty percent of the sample was male and $40 \%$ female. Eighty two of the participants were urban (living in Addis Ababa) and 33 were rural (living in Asella). In terms of religion, 32\% identified as Christian, $17 \%$ as Muslim and $49 \%$ as Ethiopian Orthodox Christian. The mean age was 28.52 years ( $\mathrm{SD}=10.79)$, with participants ranging in ages between 16 and 63 years old. Seventy-five participants were classified as community members, 35 were healthcare workers and 5 were traditional healers. Participants were largely from the Amhara and Oromo ethnic groups, with smaller percentages from the Tigre, Gurage and other smaller ethnic groups. Participants' income ranged from 0 to 2,000 Ethiopian birr per month, with the mean being 510.04 birr per month $(\mathrm{SD}=388.64)$. This mean income was equivalent to approximately US $\$ 65$ per month. More than $50 \%$ of the sample had post-secondary education and more than $50 \%$ was single.

\section{(Table 1)}

Instrument

The questionnaire was developed in English and then translated and administered in Amharic, Ethiopia's official and national language. Demographic information, including participants' gender, age, education, marital status, religion, place of residence and occupation, was collected. The survey instrument was an open-ended questionnaire which explored participants' perceptions of mental illness that was developed by the principal investigator. It asked about the symptoms, causes and treatments of three categories of mental illness: anxiety, depression and psychosis. These categories were selected based on the disorders that have the highest disease burden globally (Awas, Kebede, \& Alem, 1999; Ustun, Ayuso-Mateos, Chatterji, Mathers, \& Murray, 2004; WHO, 2000). Questions were classified into 4 domains: symptoms, causes, treatment and most common mental illness.

Domain 1 questions related to describing and identifying symptoms of mental illness.

How would you describe mental illness?

How would you know if someone is mentally ill?

How would you know if someone is depressed?

How would you know if someone is anxious?

How would you know if someone is psychotic?

Domain 2 questions related to explaining the causes of mental illness.

What causes people to become depressed?

What causes people to become anxious?

What causes people to become psychotic?

Domain 3 questions related to preferred treatment of mental illness

What is best way to deal with (treat) depression?

What is best way to deal with (treat) anxiety?

What is best way to deal with (treat) psychosis?

Domain 4 questions related to naming the most commonly observed and the most severe mental illnesses in the society. 
What are the most common mental illnesses in this society?

What is the most severe mental illness a person can have?

\section{Translation Process}

The questionnaire was translated by two Addis Ababa University students (a Master's level Language Studies student and an undergraduate Psychology student). The translations were then reviewed by two other native Amharic-speakers (an Amharic language instructor and a research consultant) who compared them to the original English version. If either of the reviewers noticed any discrepancy in the original translations they discussed them with the investigator and then decided how to correct any mistakes or differences. The questionnaire was pilot- tested on a small sample before final revisions were made. All translators were fluent in written and spoken English and Amharic.

\section{Reliability}

Reliability was established through inter-rater analysis of the categories used to code the interview responses. Two independent coders (research assistants) used the coding categories developed by the investigator, to code $10 \%$ of the interviews. Their individual coding was compared to each other's and to the investigator's coding. Changes were made to the coding categories based on discrepancies that were observed. Validity

To establish content validity, information about the social, cultural and political history of Ethiopia was referenced to support the appropriateness of the coding scheme and to incorporate an emic understanding of Ethiopian society into the analysis of response categories. The emic approach is one in which a single culture is examined from the context and point of view of that culture. Face validity was established by examining the presence and extent of inappropriate responses, which would indicate that the questions did not make sense or were not understood. The occurrence of such responses was very low.

\section{Procedures}

Ethical approval and a research permit were obtained from the Ministry of Health in Ethiopia. The questionnaire was administered in both face-to-face verbal and pen-and-paper written format. A research assistant, fluent in Amharic and English, administered the questionnaire under the principal investigator's supervision. Approximately $1 / 3$ of the surveys were administered by oral interview. The research assistant both asked the questions and recorded subjects' responses in Amharic while the investigator was present. The remaining $2 / 3$ of the surveys were administered in written format in Amharic, with subjects reading the questionnaires themselves and writing the answers. Administration took 30-45 minutes.

\section{Analysis of Interview Data}

The data were analyzed using open coding to identify salient themes in the interview responses. The coding occurred in several phases. The first step was breaking down the interview questionnaire into conceptual domains: 1.) defining mental illness and its symptoms; 2.) explaining its causative factors; 3 .) identifying preferred treatment practices; and 4.) identifying the most common and most severe mental illnesses in the society. Each domain included at least three questions, pertaining to an explanation of depression, anxiety and psychosis. Next, all of the questionnaire interviews were reviewed, by domain, to identify and record each core idea contained in the responses. An individual response could, and often did, contain more than one idea. Similar response ideas within each domain were grouped together.

\section{Revising Categories and Themes}

After each category was identified, the first draft of the coding scheme was complete and was then used to code $50 \%$ of the interview responses. Categories were then revised, including aggregating some categories, splitting others and creating new categories. Then, all of the data were coded using the revised coding scheme. Finally, 2 independent coders checked the reliability of the codes and determined, along with the investigator, any further revisions that were needed by coding $10 \%$ of the responses. As a result, there was one final revision of categories. All of the data were then recoded with the new coding categories. (Methods excepted from Monteiro \& Balogun, 2013).

\section{Results}

Responses were categorized as focusing on spiritual, psycho-cultural or socio-economic explanations of mental illness. Spiritual concepts are those that relate to supernatural indicators, causation or treatment practices, such as spirit possession, evil eye (buda), use of holy water, prayer, traditional practices, etc. Psychocultural concepts are those that are related to Ethiopian cultural values and standards of personal character, behavior and psychological appropriateness that the society expects its members to uphold. Socio-economic 
responses are those that mention financial, employment or other economically based environmental deficiencies, such as loss or property or damage due to societal catastrophes. Specific responses emphasized: behavioral, cognitive and emotional disturbance; impairment in basic functioning and personal care; social /relationship difficulties; somatic symptoms and biological causes; behaving, thinking and interacting with others in culturally inappropriate ways; religious and supernatural themes; and substance abuse (see Monteiro \& Balogun, 2013).

The most common responses to each question by residence (urban vs. rural) are shown in Table 2. For most questions, the most frequently cited response was the same for rural and urban residents. However, the modal response was different for urban and rural residents for the questions: What causes people to become psychotic? (Urban residents cited excessive worrying, rural residents cited financial problems); What is the most common mental illness in the society? (Urban residents cited madness, rural residents cited spiritually caused illness); and What is the most severe mental illness a person can have? (Urban residents cited madness; rural residents cited spiritually caused illness).

(Table 2)

In terms of treatment preferences, when asked if they would utilize modern medical treatment, traditional treatment or both, $54.5 \%$ of rural residents and $41.5 \%$ of urban residents preferred modern treatment alone, $21.2 \%$ of rural residents and $14.6 \%$ of urban residents preferred traditional treatment alone, and $24.2 \%$ of rural residents and $37.8 \%$ of urban residents preferred the use of both (Table 3 ).

\section{(Table 3)}

The prevalence of the three response types (Spiritual, Psycho-cultural and Socio-economic) was compared between urban and rural respondents. For 5 of the 13 questions, there were significant differences in the use of spiritual, psycho-cultural, and socio-economic responses by rural and urban residents (Table 4).

(Table 4)

\section{Discussion}

Behavioral and emotional disturbances were cited as the primary indicators of mental illness for both urban and rural residents. Excessive worry and death of loved one were cited by both urban and rural residents as causes of anxiety and depression, respectively. Excessive worrying was most frequently identified by urban residents as the cause of psychotic disorders, while rural residents identified employment and economic difficulties. Finally, both urban and rural residents listed advice and counseling as the best treatment of depression and anxiety and both groups cited psychiatric treatments such as medication or formal therapy with a psychiatrist or psychologist for psychotic symptoms.

Urban and rural residents had many similarities in their modal response categories. There were three questions on which urban and rural residents differed in their most frequent response. For the question "what causes people to become psychotic?" urban residents cited excessive worrying and fear and rural residents cited financial, economic problems most frequently. For the questions "what are the most common mental illnesses and what are the most severe mental illnesses in the society?" urban residents answered madness / bizarre behavior and rural residents answered spiritually or magically caused illnesses. Rural residents are more concerned than urban residents with financial and spiritual vulnerability.

In terms of general treatment preferences, both groups overwhelmingly indicated modern psychiatric treatment was the best option to treat mental illness. However, rural residents were more likely to endorse traditional treatment and urban residents were more likely to cite a combination of modern and traditional treatment.

\section{Spiritual, psycho-cultural and socio-economic variables}

The question of whether urban and rural residents would differ in their use of spiritual, psycho-cultural, and socio-economic explanations in their answers was explored. These three variables were examined because of their salience within Ethiopian culture and focus on them in the literature (Alem, Jacobsson, Araya, Kebede, \& Kullgren, 1999; Mulatu, 1999; Young, 1975). Responses from at least one of these categories were included in almost all respondents' answers.

As far as the specific relationship between residence variable and the use of spiritual, psycho-cultural and socio-economic explanations, there was a significant association between the spiritual response category and the residence variable for the question "what are the most common mental illnesses?" Rural residents were more likely to use spiritual explanations. There was also a significant association between the psycho-cultural response category and the residence variable for several questions: "how would you describe mental illness?" "what causes depression?" "what causes psychosis?" and "what is best way to treat depression?" Here, urban residents were more likely to use psycho-cultural explanations. Finally, there was a significant association 
between the socio-economic response category and the residence variable for the questions: "what causes depression?" "what causes psychosis?" and "what is the most common mental illness?" such that rural residents were more likely to use socio-economic explanations.

As previously stated, much has been written about the mental health impact of urbanization in Africa and in developing countries. Urbanization has been less often examined as a significant factor in how people actually understand and make sense of what mental illness is. It is meaningful that in this population urban and rural residents differed in their use of all three of the salient variables (spiritual, psycho-cultural and socioeconomic) for five of the questions. It makes sense that economic explanations would differ for rural and urban residents, as many rural residents migrate to urban areas because of waning economic opportunities in rural areas (Beiser \& Collomb, 1981). Also, there is evidence of the psychological toll of the complex socioeconomic stressors that rural residents experience (Cheng et al., 1995). This is a reality in Ethiopia, especially in the face of changing economic and environmental landscapes that increasingly erode traditional ways of life and values, perhaps more disruptively so than in urban environments. These traditions are what are thought to be protective about rural environments. On the other hand, it could also be argued that the economic concerns of both urban and rural residents are similar in a poor nation such as Ethiopia. The main difference may be in the perception of available financial and economic opportunities and a greater sense of vulnerability to poverty and socio-economic fluctuations. People migrate because of both the reality and the perception of greater opportunities. Studies also pointed out the significance of the stress related to migration (Beiser \& Collomb, 1981; Marsella, 1998). It would have been interesting to have had more detailed information about how many of the urban residents were actually migrants from rural areas and whether or not the migration process had affected their experience of and ideas about mental illness.

Related is the issue of traditional lifestyles acting as a buffer against mental illness. People weren't asked directly about their opinions of this, but there was evidence that this belief was supported by the numerous responses - particularly those that were part of the psycho-cultural variable - that included answers about the role of breaking tradition in causing or being a sign of mental illness, and the role of reclaiming or maintaining tradition as a significant component of treating or curing illness. Interestingly, for the questions where there were differences in the use of psycho-cultural explanations, urban residents were more likely to use such responses. This could speak to urban respondents holding on to the notion that more traditional lifestyles and values, which they don't experience to the same degree as rural residents, are in fact a protective buffer that they don't have.

It is not surprising that rural residents cited spiritual explanations more than urban residents given findings on rural Ethiopians' attitudes about epilepsy (Tekle-Haimanot et al., 1991) and observed differences in urban and rural residents' perceptions of mental illness (Alem et al., 1999). For many of the previously mentioned reasons the rural environment, despite disruptions occurring there, seems more conducive to the maintenance of traditional, particularly spiritual, beliefs. The degree to which urban and rural residents differ in their cultural and social values deserves further exploration.

\section{Conclusion}

These findings are important for mental health and public health professionals who may be trying to address health care disparities between mental health care in urban and rural regions of Ethiopia. Determining how to raise awareness about the impact of mental illness, allocate funds for sensitising and educating the public, and develop treatment programs all depend on accurate understandings of how different segments of the population view the issue of mental illness. The rural population's adherence to spiritual explanations, particularly for serious psychotic symptoms, and their openness to both modern and traditional treatments speak to the importance of developing a holistic and inclusive approach to psycho-education and treatment for this population.

There is also an interesting acknowledgement of the larger environmental and economic contributors, as well as the more circumscribed cultural and behavioral /psychological influences on mental illness. The notion arises that, indeed, Ethiopians have a holistic conceptualization, which includes broad environmental, individual behavioral, and social factors.

It is clear that continued research on perceptions of mental illness in Ethiopia is an absolute must. The effectiveness of a qualitative survey in obtaining rich and fertile responses has been demonstrated. The use of both standardized and open-ended questionnaires could be quite valuable in future research. Additionally, these findings can be added to the list of research results that will be used to help refine the development of culturally appropriate diagnostic and treatment protocols as the country continues to develop its mental health care infrastructure.

The fact that this research was conducted in a foreign language in which the investigator is not fluent is the greatest weakness of the study. However, it is hoped that this study, despite its limitations, will have contributed to the understanding of mental illness in Ethiopia and encourage more research in this area. 


\section{Acknowledgements}

This study was part of a larger dissertation research that was supported by funding from the National Security Education Program's David L. Boren Fellowship. A second study entitled, Perceptions of mental illness in Ethiopia: A profile of attitudes, beliefs and practices among community members, healthcare workers and traditional healers, is also published from this research. Special thanks to Dr. Habtamu Wondimu in the Psychology Department at Addis Ababa University and Henock Teklemichael, Gemede Hundie and Dr. Mesfin Mulatu who provided research and translation assistance. Last, but not least, thanks to Dr. Ometha Lewis-Jack for her guidance throughout the process.

\section{References}

[1] Alem, A., Jacobsson, L., Araya, M., Kebede, D., \& Kullgren, G. (1999). How are mental disorders seen and where is help sought in a rural Ethiopian community? Acta Psychiatria Scandinavia, 100, 40-47.

[2] Almeida-Filho, N., Mari, J., \& Coutinho, E. (1995). Rural urban migration and mental health in Latin America: The debate continues. In T. Harpham \& I. Blue (Eds.), Urbanization and mental health in developing countries (41-61). Brookfield, VT: Ashgate.

[3] Awas, M., Kebede, D., \& Alem, A. (1999). Major mental disorders in Butajira, southern Ethiopia. Acta Psychiatrica Scandinavica Supplementum, 100 (S397), 56-64.

[4] Beiser, M., \& Collomb, H. (1981). Mastering change: Epidemiological and case studies in Senegal, West Africa. American Journal of Psychiatry, 138 (4): 455-459.

[5] Blue, I., Ducci, M., Jaswal, J., Ludermir, A., \& Harpham, T. (1995). The mental health of low-income urban women: Case studies from Bombay, India; Olinda, Brazil; and Santiago, Chile. In T. Harpham \& I. Blue (Eds.), Urbanization and mental health in developing countries (75-102). Brookfield, VT: Ashgate.

[6] Bouhlel S., Ben Haouala S., Klibi A., Ghaouar, M., Chennoufi, L., Melki, W., \& El-Hechmi Z. (2012). Assessing beliefs and attitudes of relatives of patients with schizophrenia: A study in a Tunisian sample. L'Encephale...doi: 10.1016/j.encep.2012.06.012. [Epub ahead of print]

[7] Central Intelligence Agency. (2013). The World Factbook - Ethiopia. Retrieved February 15, 2013 from https://www.cia.gov/library/publications/the-world-factbook/geos/et.html

[8] Cheng, A., Soong, W., Chong, M., \& Lin, T. (1995). Urbanization, psychosocial stress, and mental illness in Taiwan. In T. Harpham \& I. Blue (Eds.), Urbanization and mental health in developing countries (62-72). Brookfield, VT: Ashgate.

[9] Cohen, B. (2006). Urbanization in developing countries: Current trends, future projections, and key challenges for sustainability. Technology in Society, 28, 63-80.

[10] Homma, M. (1991). A Japanese perspective on crowding: How well have the Japanese adjusted to high density? Psychologia: An International Journal of Psychology in the Orient, 33,128-137.

[11] Kishore, J., Gupta, A., Jiloha, R., \& Bantman, P. (2011). Myths, beliefs and perceptions about mental disorders and health seeking behaviour in Dehli, India. Indian Journal of Psychiatry, 53(4), 324-329.

[12] Madu, S.N., \& Ohaeri, J.U. (1989). The traditional healer's approach to the treatment of obsessional neurosis. A case study at Ibadan. Tropical and Geographical Medicine, 41(4), 383-387.

[13] Marsella, A.J. (1998). Urbanization, mental health, and social deviancy: A review of issues and research. American Psychologist, 53(6), 624-634.

[14] Monteiro, N.M. \& Balogun, S.K. (2013). Perceptions of mental illness in Ethiopia: A profile of attitudes, beliefs and practices among community members, healthcare workers and traditional healers. International Journal of Culture and Mental Health, (ahead of print), 1-14. doi:10.1080/17542863.2013.784344

[15] Mulatu, M.S. (1999). Perceptions of mental and physical illness in north-western Ethiopia: Causes, treatments, and attitudes. Journal of Health Psychology, 4, 531-549.

[16] Odejide, A.O., Oyewunmi, L.K., \& Ohaeri, J.U. (1989). Psychiatry in Africa: An overview. American Journal of Psychiatry, 147, 708-716.

[17] Sijuwola, O.A. (1995). Culture, religion, and mental illness in Nigeria. In I. Al-Issa (Ed), Handbook of culture and mental illness: An international perspective (65-72). Connecticut: International Universities Press, Inc.

[18] Swartz, L. (1995). The politics of culture and mental illness: The case of South Africa. In I. Al-Issa (Ed), Handbook of culture and mental illness: An international perspective (73-83). Connecticut: International Universities Press, Inc.

[19] Tekle-Haimanot, R., Abebe, M., Forsgren, L., Gebre-Mariam, A., Heijbel, J., Holmgren, G., \& Ekstedt, J. (1991). Attitudes of rural people in central Ethiopia toward epilepsy. Social Science \& Medicine, 32(2), 203-209.

[20] United Nations Department of Economic and Social Affairs. (2003). World Urbanization Prospects. United Nations Publications: New York.

[21] Ustun, T., Ayuso-Mateos, J., Chatterji, S., Mathers, C., \& Murray, C. (2004). Global burden of depressive disorders in the year 2000. British Journal of Psychiatry, 184,386-92.

[22] WHO International Consortium on Psychiatric Epidemiology. (2000). Cross-national comparisons of the prevalences and correlates of mental disorders. Bulletin of the World Health Organization, 78, 413-426.

[23] World Bank. (2013). Agriculture and Rural Development. Retrieved February 14,2013, from http://go.worldbank.org/RF3O70S7F0

[24] World Health Organization, Department of Mental Health \& Substance Abuse. (2005). Mental Health Atlas: 2005. Geneva: World Health Organization.

[25] Young, A. (1975). Magic as "Quasi-Profession." The organization of magic and magical healing among the Amhara. Ethnology, 14 (3), 245-265.

\begin{tabular}{llllll}
\multicolumn{7}{c}{ Table 1. Demographics } \\
\hline Residence & Frequency & Percent & Ethnicity & Frequency & Percent \\
\hline Urban & 82 & 71 & Amhara & 45 & 39.1 \\
Rural & 33 & 29 & Gurage & 6 & 5.2 \\
& & & Oromo & 33 & 28.7 \\
& & Tigre & 7 & 6.1 \\
& & & Other & 12 & 10.4 \\
\hline
\end{tabular}




\begin{tabular}{|c|c|c|c|c|c|}
\hline & & & Missing & 12 & 10.4 \\
\hline Education & Frequency & Percent & $\begin{array}{l}\text { Total } \\
\text { Marital } \\
\text { Status }\end{array}$ & $\begin{array}{l}115 \\
\text { Frequency }\end{array}$ & Percent \\
\hline Illiterate & 4 & 3.5 & Single & 60 & 52.2 \\
\hline Grade & 7 & 6.1 & Married & 40 & 34.8 \\
\hline Grade $\quad 9-12$ & 44 & 38.3 & Divorced & 3 & 2.6 \\
\hline $\begin{array}{l}\text { Post- } \\
\text { secondary }\end{array}$ & 60 & 52.2 & Widowed & 5 & 4.4 \\
\hline \multirow[t]{2}{*}{ Total } & 115 & & Missing & 7 & 6.1 \\
\hline & & & Total & 115 & \\
\hline
\end{tabular}

Table 2. Modal response category - most frequently cited response category for each question by residence

\begin{tabular}{|c|c|c|}
\hline Question & $\begin{array}{l}\text { Modal Category } \\
\text { Urban residents } \mathrm{N}=82\end{array}$ & $\begin{array}{l}\text { Modal Response Category } \\
\text { Rural residents } \mathrm{N}=33\end{array}$ \\
\hline $\begin{array}{l}\text { How would you describe } \\
\text { mental illness? }\end{array}$ & $\begin{array}{l}\text { Impairment in thinking and } \\
\text { communication }\end{array}$ & $\begin{array}{l}\text { Impairment in thinking and } \\
\text { communication }\end{array}$ \\
\hline $\begin{array}{l}\text { How would you know if } \\
\text { someone is mentally ill? }\end{array}$ & Bizarre / Abnormal behaviors & Bizarre / Abnormal behaviors \\
\hline $\begin{array}{l}\text { How would you know if } \\
\text { someone is depressed? }\end{array}$ & Negative affect / Emotions & Negative affect / Emotions \\
\hline $\begin{array}{l}\text { How would you know if } \\
\text { someone is anxious? }\end{array}$ & Negative affect / Emotions & Negative affect / Emotions \\
\hline $\begin{array}{l}\text { How would you know if } \\
\text { someone is psychotic? }\end{array}$ & Bizarre / Abnormal behaviors & Bizarre / Abnormal behaviors \\
\hline $\begin{array}{l}\text { What causes people to } \\
\text { become depressed? }\end{array}$ & Loss of loved one / Death & Loss of loved one / Death \\
\hline $\begin{array}{l}\text { What causes people to } \\
\text { become anxious? }\end{array}$ & $\begin{array}{l}\text { Excessive thinking \& } \\
\text { worrying / Fear; } \\
\text { Lack of confidence / } \\
\text { negativity }\end{array}$ & $\begin{array}{l}\text { Excessive thinking \& } \\
\text { worrying / Fear }\end{array}$ \\
\hline $\begin{array}{l}\text { What causes people to } \\
\text { become psychotic? }\end{array}$ & $\begin{array}{l}\text { Excessive thinking \& } \\
\text { worrying / Fear** }\end{array}$ & $\begin{array}{l}\text { Financial /Employment } \\
\text { Problems** }\end{array}$ \\
\hline $\begin{array}{l}\text { What is best way to deal } \\
\text { with (treat) depression? }\end{array}$ & $\begin{array}{l}\text { Advice \& counseling / Social } \\
\text { Support }\end{array}$ & $\begin{array}{l}\text { Advice \& counseling / Social } \\
\text { Support }\end{array}$ \\
\hline $\begin{array}{l}\text { What is best way to deal } \\
\text { with (treat) anxiety? }\end{array}$ & $\begin{array}{l}\text { Advice \& counseling / Social } \\
\text { Support }\end{array}$ & $\begin{array}{l}\text { Advice \& counseling / Social } \\
\text { Support }\end{array}$ \\
\hline $\begin{array}{l}\text { What is best way to deal } \\
\text { with (treat) psychosis? }\end{array}$ & $\begin{array}{l}\text { Modern / Psychiatric } \\
\text { treatment }\end{array}$ & $\begin{array}{l}\text { Modern / Psychiatric } \\
\text { treatment }\end{array}$ \\
\hline $\begin{array}{l}\text { What are the most common } \\
\text { mental illnesses in this } \\
\text { society? }\end{array}$ & $\begin{array}{l}\text { Madness / Bizarre \& } \\
\text { abnormal behaviors** }\end{array}$ & $\begin{array}{l}\text { Spiritually caused illness - } \\
\text { Magic ** }\end{array}$ \\
\hline $\begin{array}{l}\text { What is the most severe } \\
\text { mental illness a person can } \\
\text { have? }\end{array}$ & $\begin{array}{l}\text { Madness / Bizarre \& } \\
\text { abnormal behaviors** }\end{array}$ & $\begin{array}{l}\text { Spiritually caused illness - } \\
\text { Magic ** }\end{array}$ \\
\hline
\end{tabular}


Table 3. Crosstabs - treatment preference by residence

\begin{tabular}{|l|l|l|l|}
\hline & $\begin{array}{l}\text { Preferred Modern } \\
\text { Treatment }\end{array}$ & $\begin{array}{l}\text { Preferred Traditional } \\
\text { Treatment }\end{array}$ & $\begin{array}{l}\text { Preferred Both } \\
\text { Types of Treatment }\end{array}$ \\
\hline $\begin{array}{l}\text { Urban }[\mathbf{N},(\%)] \\
\mathbf{N}=\mathbf{8 2} *\end{array}$ & $34(41.5)$ & $12(14.6)$ & $31(37.8)$ \\
\hline $\begin{array}{l}\text { Rural [N, (\%)] } \\
\text { N=33 }\end{array}$ & $18(54.5)$ & $7(21.2)$ & $8(24.2)$ \\
\hline Total Sample & $52(45.2)$ & $19(16.5)$ & $39(34.0)$ \\
\hline
\end{tabular}

* 5 participants did not answer

Table 4. Chi-Square analyses - spiritual, psycho-cultural and socio-economic variables by residence

\begin{tabular}{|c|c|}
\hline Question & Residence Urban Rural \\
\hline $\begin{array}{l}\text { How would you describe mental } \\
\text { illness? }\end{array}$ & $\begin{array}{l}\text { Psycho-cultural } \\
X^{2}=10.49, p=.001\end{array}$ \\
\hline $\begin{array}{l}\text { How would you know if someone is } \\
\text { mentally ill? }\end{array}$ & Not significant \\
\hline $\begin{array}{l}\text { How would you know if someone is } \\
\text { depressed? }\end{array}$ & Not significant \\
\hline $\begin{array}{l}\text { How would you know if someone is } \\
\text { anxious? }\end{array}$ & Not significant \\
\hline $\begin{array}{l}\text { How would you know if someone is } \\
\text { psychotic? }\end{array}$ & Not significant \\
\hline $\begin{array}{l}\text { What causes people to become } \\
\text { depressed? }\end{array}$ & $\begin{array}{l}\text { Socio-economic } X^{2}=11.2, p=.001 \\
\text { Psycho-cultural } \\
X^{2}=13.03, p=.000\end{array}$ \\
\hline $\begin{array}{l}\text { What causes people to become } \\
\text { anxious? }\end{array}$ & Not significant \\
\hline $\begin{array}{l}\text { What causes people to become } \\
\text { psychotic? }\end{array}$ & $\begin{array}{l}\text { Psycho-cultural } \\
X^{2}=3.96, p=.047 \\
\text { Socio-economic } \\
X^{2}=9.99, p=.002\end{array}$ \\
\hline $\begin{array}{l}\text { What is best way to deal with } \\
\text { (treat) depression? }\end{array}$ & $\begin{array}{l}\text { Psycho-cultural } \\
X^{2}=9.61, p=.002\end{array}$ \\
\hline $\begin{array}{l}\text { What is best way to deal with } \\
\text { (treat) anxiety? }\end{array}$ & Not significant \\
\hline $\begin{array}{l}\text { What is best way to deal with } \\
\text { (treat) psychosis? }\end{array}$ & Not significant \\
\hline $\begin{array}{l}\text { What are the most common mental } \\
\text { illnesses in this society? }\end{array}$ & $\begin{array}{l}\text { Spiritual } \\
X^{2}=7.33, p=.007 \\
\text { Socio-economic } \\
X^{2}=11.67, p=.001\end{array}$ \\
\hline $\begin{array}{l}\text { What is the most severe mental } \\
\text { illness a person can have? }\end{array}$ & Not significant \\
\hline
\end{tabular}

